А.М. КРЕЙДА

Черкаський державний технологічний університет ORCID: 0000-0003-0581-1761

Є.А. УСЕНКО

Черкаський державний технологічний університет ORCID: 0000-0002-4560-2668

\title{
РОЗРАХУНОК ТА КОНСТРУЮВАННЯ ТАКЕЛАЖНОГО ВІЗКА ДЛЯ ПЕРЕВЕЗЕННЯ ВЕЛИКОГАБАРИТНИХ І ВЕЛИКОВАГОВИХ ВАНТАЖІВ НА АВТОТРАНСПОРТНИХ ПДПРИЕМСТВАХ ТА СКЛАДСЬКИХ КОМПЛЕКСАХ
}

\begin{abstract}
При проведенні навантажувально-розвантажувальних робіт час від часу виникають складні маніпуляції з важкими $і$ об'ємними вантажами, від чого інколи виникає загроза здоров'ю чи навіть життю людини. У даній роботі розглядається проблема використання підйомно-транспортного обладнання за умови безпечного перевезення великовагового та великогабаритного вантажу в умовах автотранспортного підприємства або вантажного комплексу. Транспортування великовагових $i$ великогабаритних вантажів або інших конструкиій здійснюється при використанні такелажних пристроїв та спеціалізованої техніки, наприклад - такелажних візків, без яких багато різних видів промисловості матимуть проблеми з транспортуванням важких вантажів, необхідних для належного виконання роботи. На основі раніше проведених аналітичних досліджень авторами роботи пропонується конструкиія такелажного візка з чотирма опорними роликами. Метою проведених досліджень $є$ встановлення розподілу реакиій на осі такелажного візка при транспортуванні великовагового або великогабаритного вантажу та проведення детального силового розрахунку пропонованої конструкиії такелажного візка на предмет міцності від навантаження вагою різної величини. За допомогою CAD/CAM системи Solidworks проведено симуляцію роботи візка під навантаженням умовним великоваговим та великогабаритним вантажем. Це дозволило отримати залежність деформаџіï опорної поверхні такелажного візка від сили, щзо діє на неї. При ицьому в дослідженні показано розподіл сил на опорну поверхню такелажного візка. Розраховані реакиї, щзо виникають в опорних точках конструкиії. Проведено розподіл реакцій на осі проєктованого такелажного візка при транспортуванні великогабаритного та великовагового вантажу. Це дало можливість визначити силу, яку необхідно прикласти до вантажу, щзоб зрушити його з місия.

Ключові слова: такелажний візок, вантажні перевезення, складські комплекси, симуляція роботи, навантаження, реакиії, сила тертя.
\end{abstract}

И.А. ШЛЕНЧАК

Черкасский государственный технологический университет ORCID: 0000-0002-5096-2414

А.В. ЙОВЧЕНКО

Черкасский государственный технологический университет ORCID: 0000-0002-7069-1092

А.Н. КРЭЙДА

Черкасский государственный технологический университет ORCID: 0000-0003-0581-1761

Е.А. УСЕНКО

Черкасский государственный технологический университет ORCID: 0000-0002-4560-2668

\section{РАСЧЕТ И КОНСТРУИРОВАНИЕ ТАКЕЛАЖНОЙ ТЕЛЕЖКИ ДЛЯ ПЕРЕВОЗКИ КРУПНОГАБАРИТНЫХ И ТЯЖЕЛОВЕСНЫХ ГРУЗОВ НА АВТОТРАНСПОРТНЫХ ПРЕДПРИЯТИЯХ И СКЛАДСКИХ КОМПЛЕКСОВ}

\footnotetext{
При проведении погрузочно-разгрузочных работ время от времени возникают сложные манипуляции с тяжелыми и объемными грузами, от чего иногда возникает угроза здоровью или даже
} 
жизни человека. В данной работе рассматривается проблема использования подъемно-транспортного оборудования при условии безопасной перевозки тяжеловесного и крупногабаритного груза в условиях автотранспортного предприятия или грузового комплекса. Транспортировка тяжеловесных и крупногабаритных грузов или других конструкиий осуществляется при использовании такелажных приспособлений и специиализированной техники, например - такелажных тележек, без которых много различных видов промышленности будут иметь проблемы с транспортировкой тяжельх грузов, необходимых для надлежащегго выполнения работы. На основе ранее проведенных аналитических исследований авторами работы предлагается конструкиия такелажной тележки с четырьмя опорными роликами. Целью проведенных исследований является установление распределения реакций на оси такелажной тележки при транспортировке тяжеловесного или крупногабаритного груза и проведения детального силового расчета предлагаемой конструкции такелажной тележки на предмет прочности от нагрузки весом различной величины. С помощью CAD/CAM cuстемь Soludworks проведено симуляцию работы тележки под нагрузкой условным тяжеловесным и крупногабаритным грузом. Это позволило получить зависимость деформации опорной поверхности такелажной тележки от силь, действующей на нее. При этом в исследовании показано распределение сил на опорную поверхность такелажной тележки. Рассчитаны реакции, возникающие в опорных точках конструкции. Проведено распределение реакций на оси проектированной такелажной тележки при транспортировке крупногабаритного и тяжеловесного груза. Это дало возможность определить силу, которую необходимо приложить к грузу, чтобы сдвинуть его с места.

Ключевые слова: такелажная тележка, грузовые перевозки, складские комплексы, симуляция работы, нагрузки, реакиии, сила трения.

I.A. SHLONCHAK

Cherkasy State Technological University ORCID: 0000-0002-5096-2414

A.V. YOVCHENKO

Cherkasy State Technological University ORCID: 0000-0002-7069-1092

A.M. KREIDA

Cherkasy State Technological University ORCID: 0000-0003-0581-1761

E.A. USENKO

Cherkasy State Technological University ORCID: 0000-0002-4560-2668

\section{CALCULATION AND DESIGN OF RIGID TROLLEY FOR TRANSPORTATION OF LARGE AND HEAVY LOADS TO TRANSPORT PLANTS AND WAREHOUSE COMPLEXES}

During reloading and unloading, large and heavy loads are sometimes difficult to handle, which sometimes endangers human health or even life. This paper considers the problem of using lifting and transport equipment under the condition of safe transportation of large and large loads in the conditions of a motor transport enterprise or cargo complex. Heavy and bulky loads or other structures are transported by means of rigging devices and specialized equipment, such as rigging carts, without which many different industries will have problems transporting the heavy loads required for proper performance. Based on previously conducted analytical research, the authors propose the design of a rigging trolley with four support rollers. The purpose of the research is to establish the distribution of reactions on the axis of the rigging trolley during transportation of heavy or bulky cargo and to conduct a detailed force calculation of the proposed design of the rigging trolley for strength from load of different sizes. With the help of the CAD / CAM system of Solidworks, the simulation of the trolley operation under the load of conditional heavy and oversized cargo was carried out. This allowed to obtain the dependence of the deformation of the bearing surface of the rigging trolley on the force acting on it. The research shows the distribution of forces on the supporting surface of the rigging truck. The reactions that occur at the reference points of the structure are calculated. The distribution of reactions on the axis of the designed rigging trolley during transportation of large and heavy cargo is carried out. This made it possible to determine the force that must be applied to the load to move it out of place.

Keywords: rigging trolley, freight transportation, warehouses, work simulation, load, reaction, friction force

\section{Постановка проблеми}

Роботи, пов'язані з навантаженням або розвантаженням великогабаритних та великовагових вантажів в умовах автотранспортних підприємств чи складських комплексів, проводяться при здійсненні різного роду складних операцій. Особливо такі операції здійснюються, коли на автомобільному 
підприємстві або в складському приміщенні застосовувати підйомно-транспортне обладнання недоцільно або немає можливості. Рішенням такої проблеми $є$ конструювання такелажних візків адаптованих до конкретного виробничого процесу автотранспортного підприємства чи складського комплексу $[1,2]$.

\section{Аналіз останніх досліджень і публікацій}

Дослідженню покращення ефективності виробничої бази автосервісних підприємств у питанні застосування підйомно-транспортного обладнання в умовах навантаження-розвантаження великовагових та великогабаритних вантажів присвячено низку наукових робіт, у яких розкрито різні аспекти цієї тематики.

Зокрема автор роботи [1] зазначає, що транспорт є однією з важливих складових виробництва та обслуговування будь якої галузі господарства. Він бере участь в усіх етапах виробничого процесу - від доставки сировини і комплектуючих до транспортування готової продукції до місць призначення. Тому підвищення ефективності підйомно-транспортних робіт за рахунок впровадження адаптивного такелажного обладнання $є$ актуальною тематикою сьогодення. Автор зазначає, що застарілі рухомий склад і виробничо-технічна база призводить до стрімкого спаду обсягів перевезень.

В роботах $[2,3]$ стверджується важливість формулювання стратегій розвитку автотранспортного підприємства $з$ позиції виробничої системи. Зазначається, що в сучасних умовах автотранспортні підприємства, а тим більше невеликі за розміром автотранспортні фірми, вимушені самостійно шукати стратегії свого подальшого розвитку в умовах досить динамічного зовнішнього середовища, реагувати на його зміни для того, щоб бути конкурентоспроможними та самодостатніми в своєму розвитку й стані. Зроблено висновок, що для сучасного автотранспортного підприємства найбільш доцільним $є$ оновлення та розширення парку транспортних засобів, спеціалізація, диверсифікація, трансформація підприємства, зокрема і у виробничій сфері.

Автори роботи [4] пропонують використовувати коефіцієнт організованості для визначення невикористаного потенціалу підприємства за різними стратегіями розвитку, зокрема і оновлення виробничої бази автотранспортного підприємства.

\section{Формулювання мети досліджень}

Метою представлених досліджень $\epsilon$ встановлення розподілу реакцій на осі такелажного візка при транспортуванні вантажу та проведення детального силового розрахунку пропонованої конструкції такелажного візка на предмет міцності від навантаження вагою різної величини. Симуляція роботи візка була проведена за допомогою CAD/CAM системи Solidworks.

\section{Викладення основного матеріалу дослідження}

Схема реакцій в підшипниках, що виникають на осях (опорні ролики) такелажного візка, зображена на рисунку 1. Апріорі відомо, що при прагненні рухати одне тіло по поверхні іншого в площині дотику тіл виникає сила опору їх відносному рухові. Цей опір називають силою тертя. Сила тертя - це проблема, яку постійно потрібно вирішувати, коли мова йде про вантажні перевезення, особливо в умовах транспортування великогабаритних та великовагових вантажів. Закономірність при цьому проста: чим більшу вагу має вантаж, тим значення сили тертя стає більшим. Для подолання сили тертя конструкція такелажного візка передбачає використання роликів [5].

3 метою подолання сили тертя під час транспортування великовагових та великогабаритних вантажів в конструкції підйомно-транспортного обладнання, зокрема спроєктованого такелажного візка, було передбачено чотири опорних ролики (рисунок 2).

При транспортуванні 1000 кг на одну вісь діс сила $G_{61}=5,0 \kappa H .3$ використанням рівняння рівноваги реакції в опорах можна розрахувати за наступним алгоритмом:

$$
\sum M_{A}=0 ; \quad \sum M_{A}=-G_{61} \cdot 37,5+R_{B} \cdot 75=0 \quad \rightarrow \quad R_{B}=\frac{G_{61} \cdot 37,5}{75}=2,5 \kappa \mathrm{H}
$$




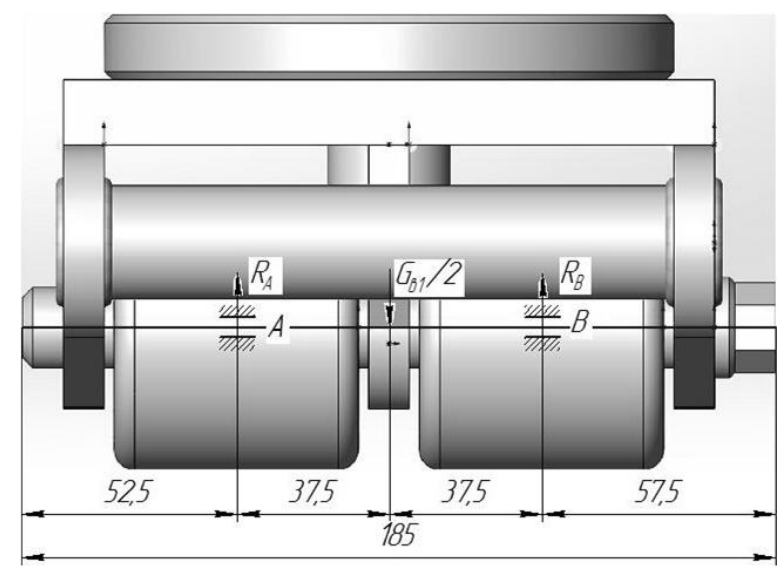

Рис. 1. Розподіл реакцій на осі такелажного візка при транспортуванні вантажу

$$
\sum M_{B}=0 ; \quad \sum M_{B}=G_{61} \cdot 37,5-R_{A} \cdot 75=0 \quad \rightarrow \quad R_{A}=\frac{G_{61} \cdot 37,5}{75}=2,5 \kappa \mathrm{K}
$$

Перевірка: $\sum Y=0 ; \quad R_{A}-G_{61}+R_{B}=2,5-5,0+2,5=0$

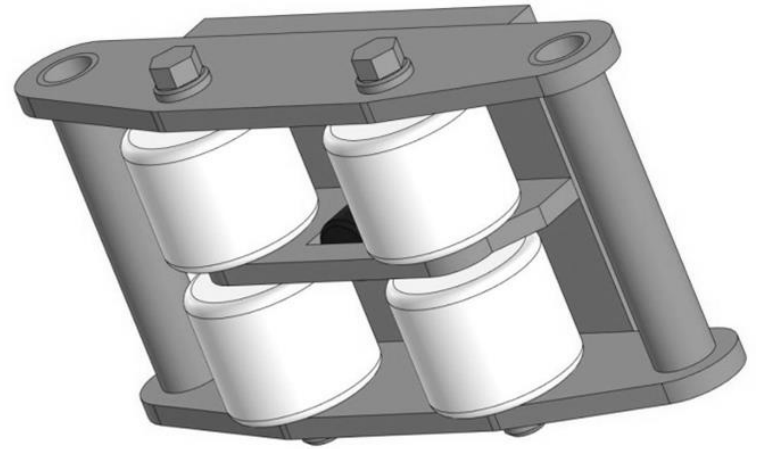

Рис. 2. Проектований такелажний візок (вигляд знизу, зображення опорних роликів)

При транспортуванні вантажу (в динаміці) виникає тертя кочення, яка схематично показана на рисунку 3. На кожний опорний ролик, перпендикулярно до його осі, прикладена горизонтальна сила $P$, що дорівнює прикладеній людиною силі при перевезенні вантажу. Крім того діє власна вага вантажу. При правильному симетричному розташуванні вантажу дана вага рівномірно розподіляється на весь такелажний візок. В системі автоматизованого проєктування SolidWorks Simulation були отримані симуляції напружень, переміщень та деформації в залежності від прикладеної сили (рисунок 4). В результаті прикладеної сили, що спричиняє деформацію, за допомогою системи Solidworks можна отримати симуляцію деформації поверхонь та отримати графіки залежностей ії величини від прикладеної до робочої поверхні сили (рисунок 5). Внаслідок деформацій ролики такелажного візка і горизонтальна опорна поверхня доторкаються один до одного вздовж деякої ділянки контакту. Нормальна реакція опорної поверхні $N$ при цьому зміщується на відстань $a$.

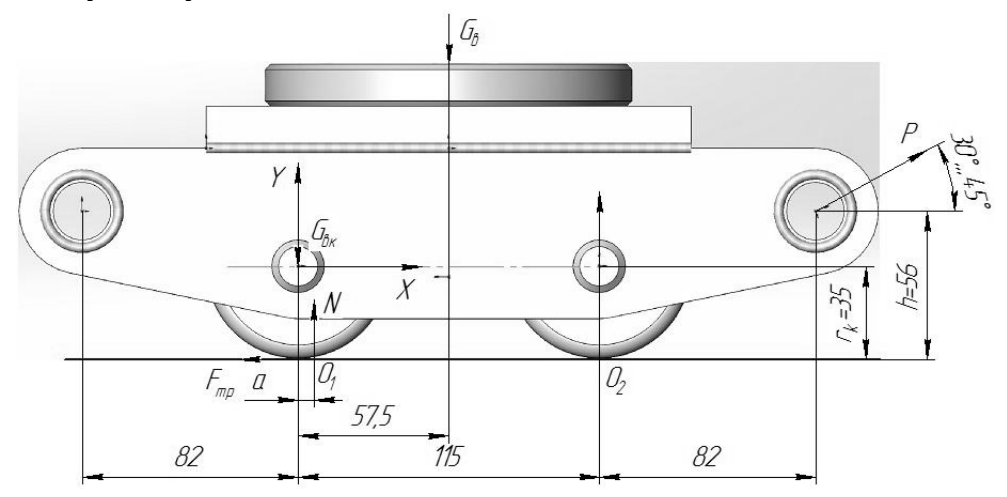

Рис. 3. Розподіл реакцій на такелажний засіб при транспортуванні вантажу 
Сила тертя $F_{m p}$ виникає в тому місці, де ролик доторкається до опорної поверхні, а саме: в точці $O_{1}$. При рівновазі ролика сила $F_{m p}$ дорівнює силі $P$, але напрямлена в протилежний бік. Таким чином, сили $P$ і $F_{m p}$ утворюють пару, яка врівноважується парою сил $G_{6 к}$ i $N$.

Момент пари сил $G_{6}$, вага вантажу, що приходиться на одне колесо, і $N$ називається моментом тертя кочення та визначається за наступною формулою:

$$
M_{m p}=N \cdot a
$$

$a$ - коефіцієнт тертя кочення, що залежить від матеріалу ролика, площини, фізичного стану їх поверхонь. Наприклад, при виборі ролика зі сталі і асфальтобетонної поверхні $a=6$ мм; при матеріалі ролика поліамід і поверхні бетон $-a=7,7$ мм.

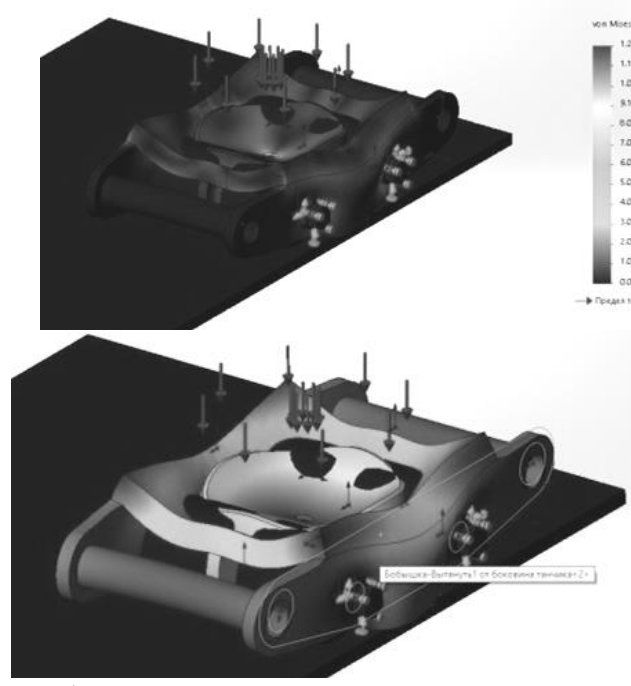

a)
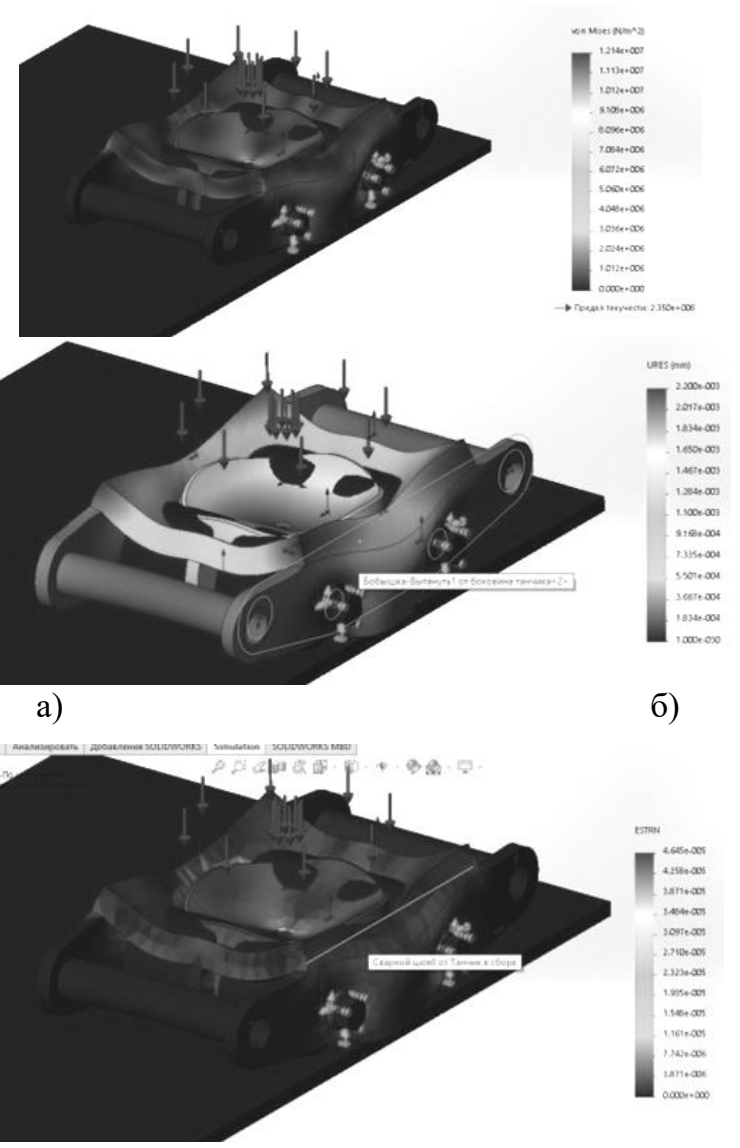

в)

Рис. 4. Розрахунок напруження (а), переміщення (б) та деформації (в), які виникають від навантаження в 10 кН на платформу такелажного візка 


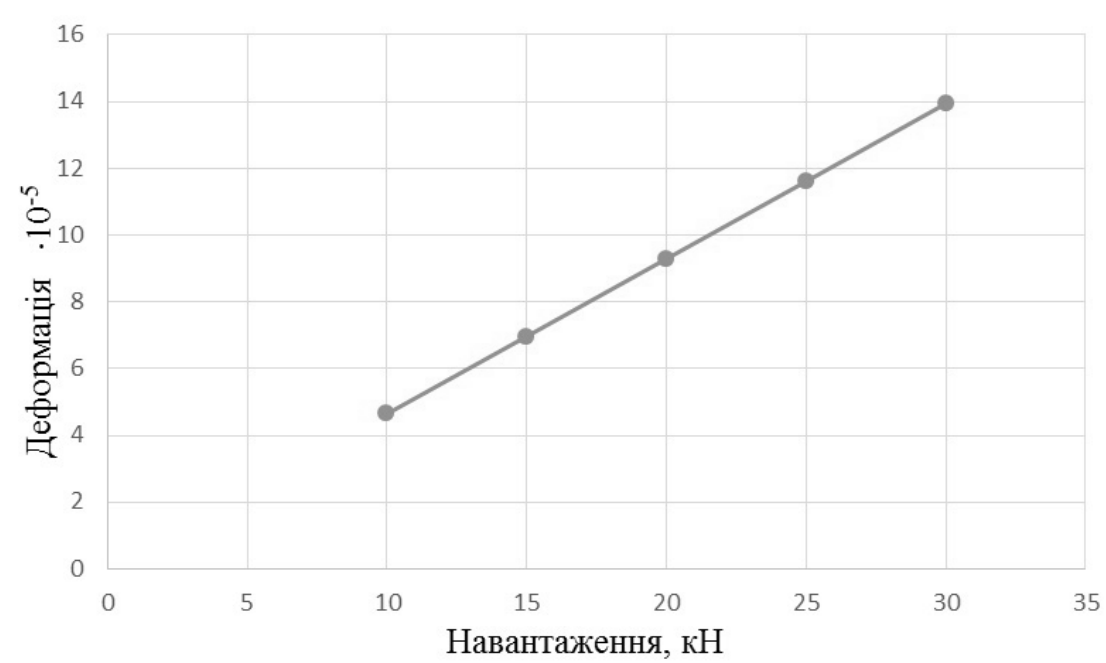

Рис. 5. Залежність деформації від сили, що діс на опорну поверхню такелажного візка

При транспортуванні вантажу масою 1000 кг, вага, яка припадає на один ролик складає $\mathrm{GB \kappa}=\mathrm{RA}=2,5$ кH. При цьому нормальна реакція опорної поверхні дорівнює $\mathrm{N}=2,5 \mathrm{\kappa H}$, тобто протилежно прикладеному навантаженню. Необхідно зазначити, що такелажний візок знаходиться в стані рівноваги, якщо момент активної сили відносно точки $O_{l}$ буде меншим від моменту тертя. Тобто у такому разі цю залежність можна описати на ступною формулою:

$$
P \cdot h \leq N \cdot a
$$

Крім того, при транспортуванні вантажу необхідно враховувати, наскільки поверхня дороги $є$ чистою, без тріщин, отворів або інших перешкод для кочення. Для того щоб вантаж зрушити з місця, потрібно, щоб момент активної сили відносно точки $O_{l}$ був більшим від моменту тертя. Тобто у такому разі залежність (4) можна зобразити наступним чином:

$$
P \cdot h \geq N \cdot a
$$

Таким чином визначаємо силу, яку необхідно прикласти до вантажу, щоб зрушити його з місця:

$$
P \geq \frac{N \cdot a}{h}=\frac{2,5 \cdot 7,7}{56}=0,36 \kappa H .
$$

Тобто, для того щоб зрушити з місця вантаж вагою 1000 кг, необхідно прикласти сили на одне колесо більше 0,36 кН, за умови, що сила прикладається під кутом $45^{0}$.

Такелажний візок - це платформа 3 опорними роликами, що застосовується для транспортування великовагового та великогабаритного вантажу. Вони повинні бути виготовлені з якісного матеріалу, оскільки на них буде чинитися великий тиск під час переміщення вантажу. Залежно від вимог доступні різні системи для утримання різних навантажень. Зазвичай вони мають кермову ручку, яка допомагає їм маневрувати після завантаження.

Більш детальна конструкція проєктованого такелажного візка зображена на рисунку 6. До потовщеної сталевої основи 1 , за допомогою пальця 2 , кріпиться на наборному упорному підшипнику 3 поворотна платформа 4, на яку безпосередньо встановлюється вантаж. Поворотна платформа повинна містити або гумову підкладку, або мати, як в нашому випадку, негладку ребристу поверхню для попередження ковзання вантажу. Також необхідно врахувати, що платформа повертається в цьому місці для керування на крутих поворотах.

3 протилежного боку основи 1 знаходиться права та ліва бічна поверхня 6 , а також центральна пластина 5, що слугують в певній мірі як ребра жорсткості конструкції. Дані поверхні беруть безпосередню участь в закріпленні чотирьох роликів 8 з поліуретановим покриттям діаметром 3 дюйми. Дані ролики є зносостійкими та слугують для плавного та стабільного маневрування. Ролики у свою чергу полегшують поворот візка 3 великогабаритним або великоваговим вантажем. Ролики фіксуються на осі 9 за допомогою гайок 10. 


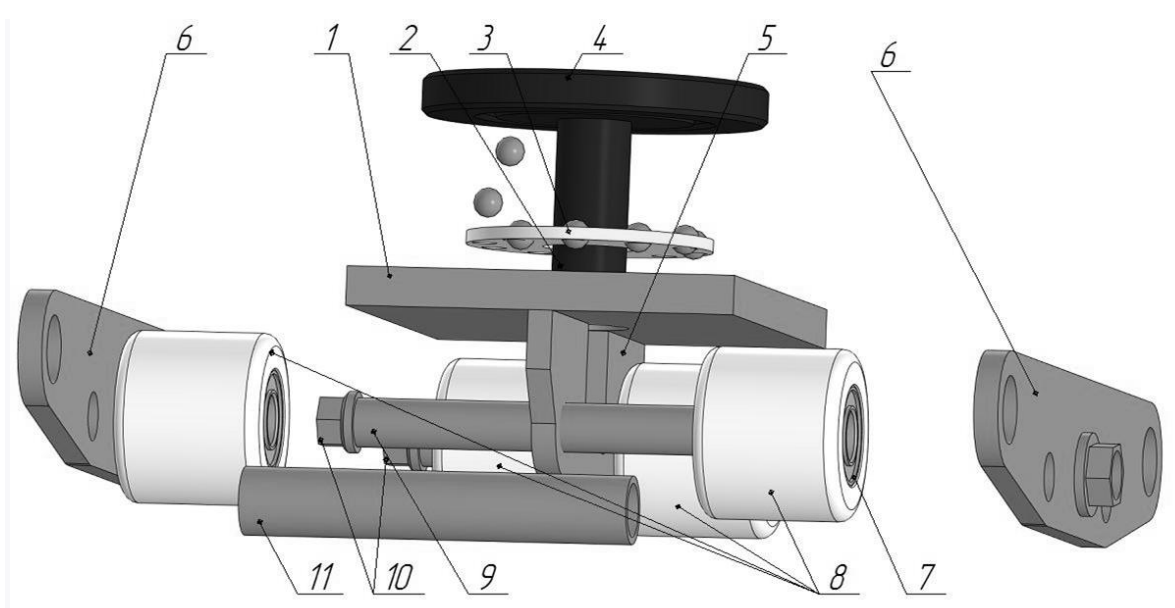

Рис. 6. Конструкція роликового такелажного візка

3 обох сторін бічних поверхонь $6 \epsilon$ вбудовані ручки 11 , що забезпечують додаткову жорсткість конструкції та застосовуються для переміщення, витягування вантажу, а також кріплення для кермової ручки. Обов'язково потрібно врахувати, що чим більша довжина кермової ручки, тим менше потрібно прикласти зусиль для переміщення вантажу людиною.

Якість роликів диктує довговічність і якість руху. Колеса, виготовлені з поліуретану або нейлону мають більш несучу здатність, ніж гумові. Крім того такі ролики $є$ стійкими до їдкого впливу олив та розчинників, вони також стійкі до розривів, стійкі до погодних умов та екстремальних температур. Крім усіх цих переваг, вони також зменшують ризик пошкодження підлоги робочого місця. Разом з тим дані ролики не рекомендуються для тривалих навантажень у стані спокою або на шорстких поверхнях кочення. Однак, сталеві колеса навпаки забезпечують максимальну міцність і витримують тривалі навантаження в стані спокою і навіть постійну установку. Вони чудово підходять для застосування 3 шорсткою або нерівною підлогою.

В кожному ролику з обох торців знаходиться голчастий однорядний закритий ущільненнями підшипник 7. Підшипник забезпечує більш довготривалі експлуатаційні можливості даного ролика та підвищує експлуатацію самого такелажного візка

Роликовий такелажний візок повинен мати конструкцію з низьким профілем для забезпечення мінімального підйому вантажів відносно поверхні, на якій він знаходиться. Це в свою чергу піднімає ефективність використання такого підйомно-транспортного обладнання в сфері переміщення великовагового та великогабаритного обладнання.

Такелажні візки дуже прості у використанні та інтуїтивно зрозумілі, тому немає потреби в отриманні довготривалих тренуваннях по їх керуванню. Необхідно зазначити, що такі візки досить безпечні та легко контролюються за допомогою ручного пристосування або автоматизованого. Таке підйомно-транспортне обладнання дозволяє здійснювати маневри 3 великогабаритними та великоваговими вантажами порівняно швидко. Коротка інструкція 3 безпечного використання проєктованого такелажного візка наведена на рисунку 7. Візки також можуть використовуватися в різних автосервісних підприємствах та вантажних комплексах через їх універсальність.
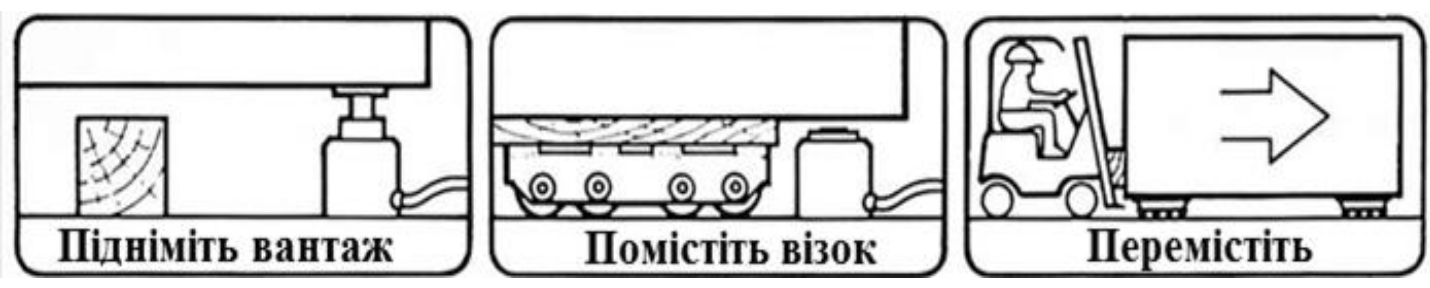

Рис. 7. Принцип використання такелажних візків для переміщення великогабаритного та великовагового вантажу

Щоб використовувати такелажні візки ефективно та безпечно, необхідно взяти чотири низько профільних підніжки. Останні застосовуються, щоб підняти вантаж, яке потрібно перемістити. Після того, як великоваговий або великогабаритний вантаж було піднято, проектовані візки розміщуються під вантаж. Вони можуть працювати як частина системи з трьома або чотирма точками навантаження. Тобто це значить, що або три візка розміщуються під вантажем, або чотири візка. Повільно відпустивши 
профільні підніжки, необхідно переконатися, що вантаж знаходиться в потрібному положенні на візках. Після цього необхідно приєднати кермові ручки і перемістити вантаж у потрібне місце. Ці ручки можна тягнути або штовхати мускульною силою людини. Разом 3 тим при достатньо великогабаритних та великовагових вантажах візок можна прикріпити до фаркопа автомобіля або іншого транспортного самохідного засобу.

\section{Висновки}

1. Проведено розподіл реакцій на осі проєктованого такелажного візка при транспортуванні великогабаритного та великовагового вантажу. Це дало можливість визначити силу, яку необхідно прикласти до вантажу, щоб зрушити його з місця.

2. Здійснено силовий розрахунок пропонованої конструкції такелажного візка на предмет міцності від навантаження вагою різної величини.

3. За допомогою $\mathrm{CAD} / \mathrm{CAM}$ системи Solidworks проведено симуляцію роботи візка під навантаженням умовним великоваговим та великогабаритним вантажем. Це дозволило отримати залежність деформації опорної поверхні такелажного візка від сили, що діє на неї.

4. Проведені в роботі дослідження дозволили визначити реакції, що виникають в результаті навантаження проєктованого такелажного візка.

\section{Список використаної літератури}

1. Біліченко В.В. Методичні основи розробки проекту стратегічного розвитку підприємств автомобільного транспорту. Наукові праці Вінницького національного технічного університету. Вінниця, 2008. № 3. C. 162-165.

2. Біліченко В. В. Передумови обгрунтування стратегічного розвитку виробничих систем автомобільного транспорту в Україні. Вісник ЖДТУ. Серія «Технічні науки», 2014. №2(69). С. $33-43$. https://doi.org/10.26642/tn-2014-2(69)-33-43

3. Лудченко А. О. Технічна експлуатація і обслуговування автомобілів: підручник. Київ: Вища шк., 2007. 527c

4. Бідняк М.Н., Біліченко В.В. Виробничі системи на транспорті: теорія і практика: монографія. Вінниця: УНІВЕРСУМ, 2006. 176 с.

5. Рівновага тіл з врахуванням тертя спокою: методичні рекомендації та завдання 3 дисципліни «Теоретична механіка» для студентів механічних та будівельних спеціальностей / Упоряд. : Л.Д. Мисник, О.В. Манзюра ; М-во освіти і науки України, Черкас. держ. технол. ун-т. - Черкаси : ЧДТУ, 2016. - 22 с.

\section{References}

1. Bilichenko V.V. Metodychni osnovy rozrobky proektu stratehichnoho rozvytku pidpryiemstv avtomobilnoho transportu [Methodical bases of development of the project of strategic development of the enterprises of motor transport]. Zbirnik naukovikh prats' Vinnytskyi natsionalnyi tekhnichnyi universytet. Vinnytsia, 2008, no 3. pp. 162-165.

2. Bilichenko V.V. Peredumovy obgruntuvannia stratehichnoho rozvytku vyrobnychykh system avtomobilnoho transportu v Ukraini. Visnyk Zhytomyrskoho derzhavnoho tekhnichnoho universytetu. Seriia «Tekhnichni nauky», 2014, no 2(69). pp. 33-43. https://doi.org/10.26642/tn-2014-2(69)-33-43

3. Ludchenko A. O. Tekhnichna ekspluatatsiia i obsluhovuvannia avtomobiliv [Technical operation and maintenance of cars]. Kiev: Higher school Publ., 2007. 527 p.

4. Bidniak M.N., Bilichenko V.V. Vyrobnychi systemy na transporti: teoriia i praktyka: monohrafiia. Vinnytsia. UNIVERSUM. 2006. 176 p.

5. Mysnyk L.D., Manziura O.V. Rivnovaha til z vrakhuvanniam tertia spokoiu: metodychni rekomendatsii ta zavdannia $\mathrm{z}$ dystsypliny «Teoretychna mekhanika» dlia studentiv mekhanichnykh ta budivelnykh spetsialnostei [Equilibrium of bodies taking into account friction at rest: methodical recommendations and tasks in the discipline "Theoretical Mechanics" for students of mechanical and construction specialties]/ Ministerstvo osvity i nauky Ukrainy, Cherkaskyi derzhavnyi tekhnolichnyi universytet. Cherkasy, 2016. p.22 